\title{
SURFACE AND SUBSURFACE KARSTIFICATION OF AQUIFERS IN ARID REGIONS: THE CASE STUDY OF CHESHME-ALI SPRING, NE IRAN
}

\author{
Mohammad Shokri ${ }^{*}$, Javad AshJarI ${ }^{2}$, AND GHolamhossain Karami ${ }^{1}$
}

\begin{abstract}
Objective karstification assessment is a key component of hydrogeological studies of aquifers. In this research, surface and subsurface karst development have been assessed, based on different methods, to get insights into karstification processes in the area of the Cheshme-Ali karstic aquifer, located in northeast Iran. GIS information, remote sensing, and field measurements of fracture density and frequency have been used to determine surface karst development. The monthly spring discharge rate and physicochemical parameters of the Cheshmeh-Ali Spring in 2003-2004 were used to determine subsurface karstification rate. Additional monthly measurements of discharge rate and chemical parameters were carried out in 2010-2011. The evaluation of surface karstification $\left(S_{k}\right)$ illustrates moderate karstification of 51.47 percent. The response of the aquifer to precipitation shows the impact of one or more conduits in the water level fluctuation zone that generate a rapid response of the spring to large precipitation events. The spring hydrograph analysis indicates a pseudo-diffuse flow system in the region. The hydrograph and chemograph analyses demonstrate average subsurface karstification index of $1.7 \mathrm{~m}$. Finally, it is concluded that although both methods demonstrate karstification processes in an aquifer, these kind of reservoirs still require more intelligible approaches, as well as comparable methods for their description.
\end{abstract}

\section{INTRODUCTION}

Karstic aquifers are the most attractive reservoirs for water exploitation. These aquifers are very important resources of water supply in arid and semi-arid regions. While demand for water is high in dry regions, access to surface water is very limited. Aquifers store groundwater during the wet season, then naturally release it gradually to surface springs or rivers.

It is crucial to identify surface and subsurface karstification processes. Typical karst topography is related to subterranean drainage, and therefore, geomorphology and hydrology are closely interrelated (De Waele et al., 2009, 2011). Aerial photograph and satellite image interpretation may be of considerable help in the identification of the karst surface landforms. Techniques are currently supported by automatic tools with a high potential for graphical representation of karst development, such as GIS with incorporation of remotely sensed data. These types of data have significant advantages over traditional methods because they can cover broad areas relatively quickly, have better accuracy and precision, are accessible in a digital format, and can be easily updated (Melelli et al., 2012).

However, field mapping and acquisition of geological data remain the best way of obtaining accurate information to check the validity of the interpretation of the GIS data. Deducing the principles of karstification from geological structures were highlighted in the works of White (2002) and Ford and Williams (2007). According to Jameson (2006), in order to study karst evolution, structural features should be identified and analyzed. Features most commonly develop along preexisting fractures, joints, and bedding planes, which represent the initial flow path of the water through the rock. Over time, a variety of larger features can develop into cave systems, with sinkholes and deep valleys as surface expressions that control surface development of karst landscapes (Šebela et al., 2005; Parise, 2008; Pepe and Parise, 2014; Gutiérrez et al., 2014). Fractures play an important role in transmitting water from diffuse recharge on the land surface to the conduits, as well as to wells drilled in karst aquifers (Kiraly, 2003). Water flow will enhance the dissolution, particularly in fractures with large apertures.

Karst-spring hydrograph and chemograph analyses are the signature of subsurface karst development. Panagopoulos and Lambrakis (2006) demonstrated that by studying time-series analysis of rainfall as input and spring discharges as output along with hydrodynamic and recession curves analysis we can evaluate the whole of karst aquifers. The response times of karst aquifers depend on various factors, such as the contribution of allogenic recharge and internal runoff, the carrying capacity and internal structure of conduit system, and the area of the groundwater basin (White, 2002). The combined analysis of karst spring hydrographs and chemographs allows a more refined characterization of the karst drainage systems (Drake and Harmon,

\footnotetext{
*Corresponding author: Shokri.m20@gmail.com

${ }^{1}$ Department of Earth Sciences, Shahrood University of Technology, Iran

${ }^{2}$ Department of Earth Sciences, University of Tehran, Iran
} 


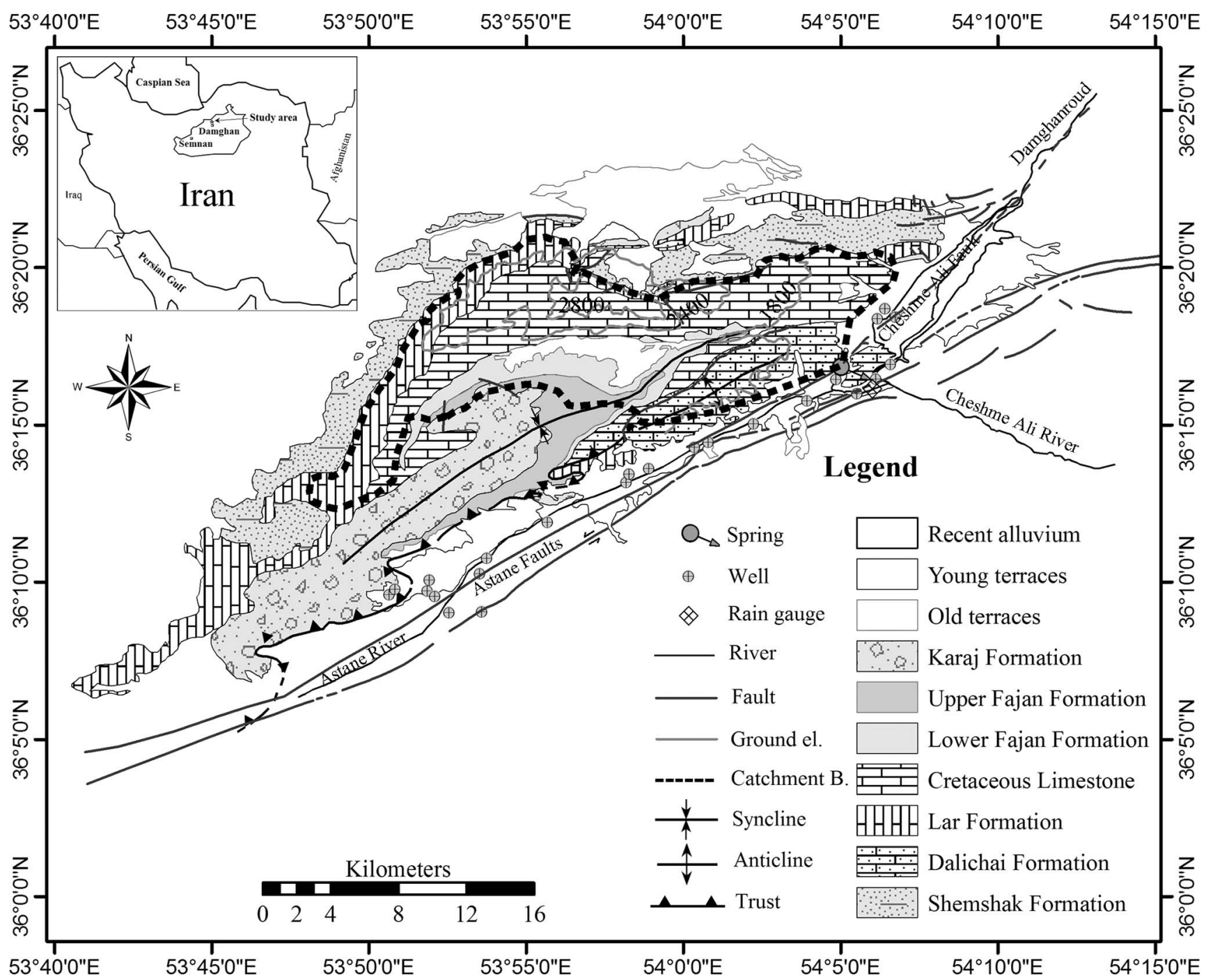

Figure 1. The location and geological map of the study area.

1973; Sauter, 1992; Jeannin and Sauter, 1998; Dewandel et al., 2003; Parise et al., 2015).

The object of this study is to evaluate surface and subsurface karstification in a catchment area of a permanent and high flow karstic spring located in an arid region of Iran. The study area is the basin of Cheshme-Ali Spring, with average discharge rate of about $500 \mathrm{~L} \mathrm{~s}^{-1}$ and mean annual rainfall of about $257 \mathrm{~mm}$.

\section{Identification and Geological Setting of STUDY Area}

The study area is situated in the province containing the city of Damghan in northeastern Iran. The geological map and the stratigraphical units of this area are shown in Figure 1. The region lies in the Alborz Ridge Mountains of Iran. The Cheshme-Ali Basin consists of two series of tight anticlines, with the northern limb of the northern anticline eroded (Shokri et al., 2011). The Shemshak Formation,
Early Triassic to Middle Jurassic, consists of fine sandstone, siltstone, and shale, and is over $1020 \mathrm{~m}$ thick (Aghanabati, 2006). Hydrogeologically, the formation is the bedrock of the Cheshme-Ali Basin's aquifer. The Dalichai Formation is a Middle Jurassic marly limestone with a thickness of more than 100 meters that crops out at the southern limb of the southern anticline. The limestone of the Lar Formation, Late Jurassic, and the Cretaceous Formation are the main karstic aquifers exposed in the area. The karstic formations are underlain and overlain by impermeable sandy marl of the Shemshak and Fajan Formations, respectively. The Fajan Formation (Paleocene-Eocene) consists of conglomerates, red sandstones, and sandy marl. The Karaj Formation (Middle Eocene) is composed of green tuff with frequent sandstone fragments.

Geomorphologically, several micro-karst landforms have been observed in abundance on the exposed limestone, but the field investigations showed no solution features such as sinkholes, caves, dolines, shafts, or closed depressions 
and highlighted the important role played by structural elements such as faults, joints, folds, and bedding planes. Two major faults controlled the basin development. The Astane Fault, a reverse left-lateral displacement fault, crosses south of it and is $75 \mathrm{~km}$ in length, and the Cheshme-Ali Fault shows a trend of N50E. Several minor normal, trust, or strike-slip faults cross the basin (Shokri et al., 2011; Shokri, 2012).

The highest, mean, and lowest elevations of the catchment basin are 3200, 2100, and 1510 m.a.s.1., respectively. No rain gauge station is located in the catchment area of the spring. According to the recorded data at the nearest rain gauge, about $2.5 \mathrm{~km}$ south from the spring and at $1450 \mathrm{~m}$ elevation, the long term mean annual rainfall is $129 \mathrm{~mm}$. Several rivers cross the area, but none of them cross the anticlines. The rivers are ephemeral, largely fed by the upstream surface watershed, and are dry for much of the year (Fig. 1). A qanat is a man-made horizontal gallery to collect groundwater by gravity flow (Wulff, 1968). Neither wells nor qanats were built to exploit water from the karst layers. Twenty-four wells were identified that extract groundwater from the alluvial aquifer adjacent to the karst aquifer.

\section{Methods}

The following data were used in this research: 1:25000 topographic maps, 1:100000 geologic maps, 2001 Landsat images, 2007 panchromatic IRS images, long-term records of 14 rain gauges, and temperature data of the region's weather stations, as well as discharge, specific conductance, water temperature, $\mathrm{pH}$, and major ions of the spring water. The data were obtained from a variety of sources, including the Geology Survey of Iran, Regional Water Board of Semnan, Space Organization of Iran, Karami (2004), and Survey Organizing of Iran. The present research is based on GIS and remote sensing systems, field studies, and physicochemical interpretations of the Cheshmeh-Ali Spring.

GIS techniques and remote sensing were used to determine the surface karstification factors in the study area. Lithology, topography, vegetation, lineament density and spacing, fault density and spacing, drainage network, temperature, and precipitation were used as interpretation elements to extract the thematic layers. The overlay of these map layers in GIS produces a composite map of the karstification components. To determine which factors affect surface karstification and to what degree, experts were consulted to provide judgments on importance of criteria. By using the analytic hierarchy process (AHP), a score for each criterion $\left(X_{i}\right)$ on each layer was determined. These considerations were then converted to criteria weights $\left(W_{i}\right)$. The AHP technique is based on a pair-wise criteria comparison that has been widely used in geosciences and other fields as well (e.g., Ho, 2008; Sinha et al., 2008; Mondal and Maiti, 2013; Daman Afshar and Majlesi, 2013).
The weighted linear combination of $W_{i}$ and $X_{i}$ results in a karstification index for each layer. By the above process, the surface karstification map was produced. Several field checks have been completed to assess and validate the procedure. The field studies also included measurements of orientation, spacing, and aperture of fracture elements.

The Cheshmeh-Ali Spring's physicochemical parameters were used to determine the subsurface karstification in the basin. As an index of karstification, the recession coefficient of the spring hydrograph was determined using Mangin's method (1975). The Grasso et al. (2003) method of comparison of the variation of spring water chemistry to discharge was also used to study subsurface karstification.

\section{Results And Discussions}

\section{Catchment Area of Spring}

The catchment area of Cheshme-Ali's Spring was determined using the method of Ashjari and Raeisi (2006). This method assumes that there is no allogenic stream input and that the variation of storage over the measured hydrological year is insignificant. In $A=V /\left(10^{3} P I\right)$, $A$ is the catchment area of the spring $\left(\mathrm{km}^{2}\right), V$ the total discharge of the spring during one hydrological year $\left(\mathrm{m}^{3}\right)$, $P$ the average annual precipitation $\left(\mathrm{mm}^{-1}\right)$, and $I$ is a recharge coefficient (dimensionless) that varies from 0 to 1 . The calculated catchment area should be compared to the probable boundary of the spring watershed area.

The mean discharge of the spring was $411 \mathrm{~L} \mathrm{~s}^{-1}$ during the hydrological year 2003-2004. The comparison of the spring discharge at the beginning and end of the year demonstrated negligible variation in the aquifer storage. Using a rainfall elevation equation of the region, average precipitation $P$ was estimated to be $257 \mathrm{~mm}$. Field verifications of morphology and the existence of valleys that are normally dry except for temporary water runoff due to heavy rains indicate low permeability of the rock mass. The recharge coefficient $I$ was estimated to be 0.38 according to Ashjari and Raeisi (2006). The geological setting and the water budget calculation have shown that the catchment area of the Cheshme-Ali Spring is about $132 \mathrm{~km}^{2}$ and is restricted to the northern and southern limbs of the calcareous and marly limestone anticlines (Fig. 1).

The exposed cores of the anticlines are dominantly made of the calcareous Lar and Cretaceous Formations and of the marly limestone of Dalichai Formation. There is no hydraulic connectivity between the northern and southern limbs in most parts of the anticlines, except in the plunge apexes, because the elevation of the Shemshak Formation under the crest of the anticline is higher than the adjacent alluvial aquifers in these areas. Karst water originates from the calcareous formations and discharges at the spring. Therefore, karst water from the limbs is expected to flow along the foot of the anticlines and finally 


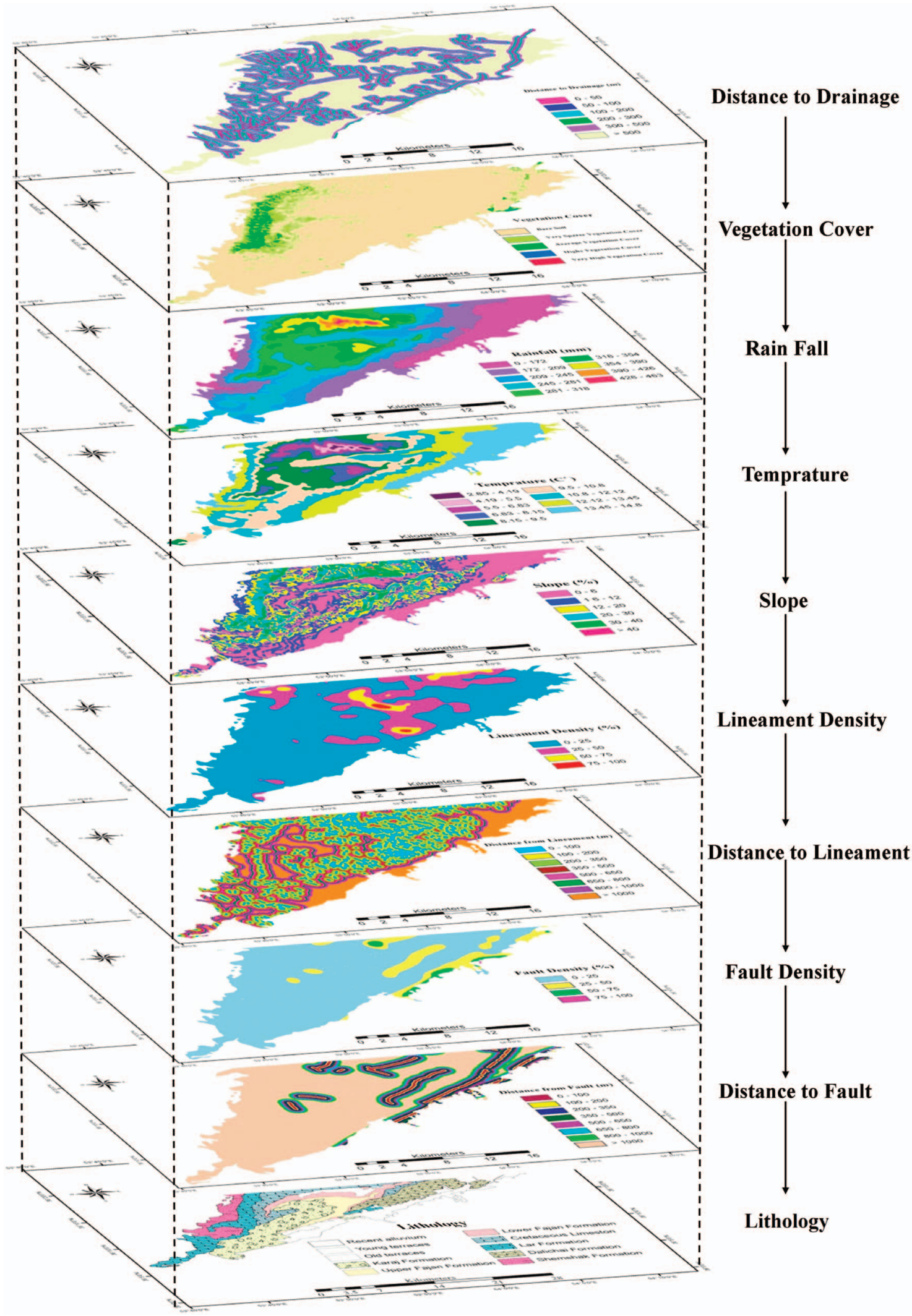

Figure 2. The ten database layers used in the GIS analysis, prepared as described in the text. 
emerge from the Cheshme-Ali Spring, which acts as the local base level of the aquifer.

\section{GIS and Remote-Sensing Method}

Remote-sensing and GIS techniques were used to create a surface karstification map in the region. The GIS technique contains several layers of information, combining the data collected from the various sources and integrated into the system. To facilitate access to specific categories of information, these were combined within 10 main layers: lithology, distance to faults, fault density, distance to lineament, lineament density, slope, temperature, rainfall, vegetation cover, and distance to drainage (Fig. 2). Since nearly the whole catchment is bare and without soil cover, we did not consider a soil cover layer in this research. The lithology layer was based on published geological maps, satellite images, and field checks. Carbonate successions of the area were considered as karstifiable layers, whereas alluvial and sandy marly formations are unkarstified rocks. The Dalichai, Lar, and Cretaceous Limestone Formations consist of carbonate rocks with different level of purity. According to Stöcklin and Setudehnia (1971), the Dalichai Formation is less pure than the other carbonate layers.

Faults can guide water to penetrate into the ground; therefore, karstic processes can developed along them and result in a variety of karst morphologies (Jafarbeyglou et al., 2012). Large faults are rarely represented by a single surface fracture. Minor faults usually feather off at acute angles as a consequence of the wrenching of the rock. Shear fractures are often oriented parallel to or close to the associated structures (Ford and Williams, 2007). Opportunities for karst development are most likely in the center of the fault zone. A distance map to faults was prepared in GIS. To score fault effects on karstification, the inverse distance weighting to center method was used. The highest score was given to the center zone of the faults, and the lowest score to distances farther than one kilometer from middle line. We used nine distance zones: 0-100 m, $100-200 \mathrm{~m}, 200-350 \mathrm{~m}, 350-500 \mathrm{~m}, 500-650 \mathrm{~m}, 650-800 \mathrm{~m}$, $800-1000 \mathrm{~m}$, and $>1000 \mathrm{~m}$. The margin of the Astane Fault achieved the highest score.

The fault-density map was prepared by the density function of ArcGIS and classified into four density zones, $0-25 \%, 25-50 \%, 50-75 \%$, and $75-100 \%$.

The zones with the highest lineament density are often those with the most intense karst development (Goldscheider and Drew, 2007). Lineaments have a narrow, linear trend and are detectable on high-altitude and satellite images (Ford and Williams, 2007). In this study, lineaments were detected by high-pass directional filters and edge enhancement filter on IRS panchromatic images in four directions by ILWIS 3 software. Maps of lineament are important tools that may help to designate karstifiable sites. Two sets of thematic maps were prepared to include lineament effect on karst development: lineament density and inverse distance weighting to lineament. A distance map of lineaments was prepared, subdividing the area into nine zones: $0-100 \mathrm{~m}, 100-200 \mathrm{~m}, 200-350 \mathrm{~m}, 350-500 \mathrm{~m}$, $500-650 \mathrm{~m}, 650-800 \mathrm{~m}, 800-1000 \mathrm{~m}$ and $>1000 \mathrm{~m}$. The trends of lineaments are N60E to N90E, and N60W to N90W. The lineament density map was prepared by the density function of ArcGIS, and classified into four groups: $0-25 \%, 25-50 \%, 50-75 \%$ and $75-100 \%$. The highest densities are distributed in the crests and at the north plunge of the anticlines.

The slope map was derived from a digital elevation model. The slopes were classified into six classes. The slope class of $0-6$ degrees dominated the map, followed by $6-12$ degrees. The lower average slopes were observed at the limbs, footslopes and crest line of folds. There is an inverse relationship between slope and karstification; gentler slopes promote karst development (White, 1988). Therefore, the lowest score was assigned to the steepest slopes.

The main source of recharge is autogenic, from direct precipitation over the karstic aquifer of the area. The temperature has an inverse effect on the karstification rate. Precipitation, rather than temperature, is the principal meteorological control on solution (Ford and Williams, 2007). Thematic maps data of precipitation and temperature were derived by applying rainfall-elevation and temperature-elevation relations to the DEM data. On their map layers, precipitation and temperature are classified into nine groups. The peaks of anticlines had the highest precipitations and lowest temperatures, which received the highest scores.

Vegetation is found to have an important role in surface karst development through absorption of calcium and magnesium by roots and carbon dioxide production (Ford and Williams, 2007). The normalized-difference vegetation index (NDVI) was used to prepare the layer for vegetation cover. The NDVI is directly related to photosynthetic capacity and, therefore, to the karstification capacity. The vegetation map shows five types of vegetation cover in the area: bare, very weak, weak, average, and intense, based on the NDVI. The intense-vegetation spots were distributed in the northwest of the catchment area. The basin is mostly classified as having an average vegetation cover.

The drainage pattern is distinguished from other types of lineaments to highlight its role on karstification. The drainage information was derived from the topographic maps at 1:25000 scale and the panchromatic IRS images of the area. Then a map was prepared in GIS of the distance to drainage grouped into six stages, $<50 \mathrm{~m}, 50-100 \mathrm{~m}$, 200-300 m, 300-500 m, and >500 m. In the study area, the northern anticline has a tighter drainage pattern than the southern anticline.

To assign a weight to each layer, previous research and personal judgment have been used. It is extremely difficult to assign weights for relative karstification to the 
Table 1. The weights (\%) given to the GIS data layers in Figure 2 to generate final surface karstification map.

Data Fault Lineament Distance to Distance to Vegetation Distance to

Layer Lithology Precipitation Density Density Faults Lineaments Cover Drainage Slope Temperature

\begin{tabular}{lllllllllllll} 
Weight & 24 & 13 & 18 & 15 & 11 & 9 & 5 & 2 & 1 \\
\hline
\end{tabular}

different layers involved in basin mapping for relative karstification. The final weights given to the categories in the ten data layers, which were determined by using the analytic hierarchy process, are listed in Table 1.

The final relative surface karstification map is presented in Figure 3. The accuracy of this model has been verified by field checks. The karstified rocks of the catchment are classified into four groups (Table 2). Non-karstified sections coincide with non-carbonate layers, and highly karstified zones are in the northern anticline of the springwater catchment.
The average surface karstification $\left(S_{k}\right)$ as a percentage was calculated by

$$
S_{K}=\frac{\sum_{i=1}^{n}\left(A_{i} K_{C_{i}}\right)}{A} \times 100
$$

where $A_{i}$ represents the area of each karstification class, $K_{C_{i}}$ represents the karstification coefficient of that class and $A$ represents the catchment area of aquifer. In each class, overall distributive pixelated size of potential

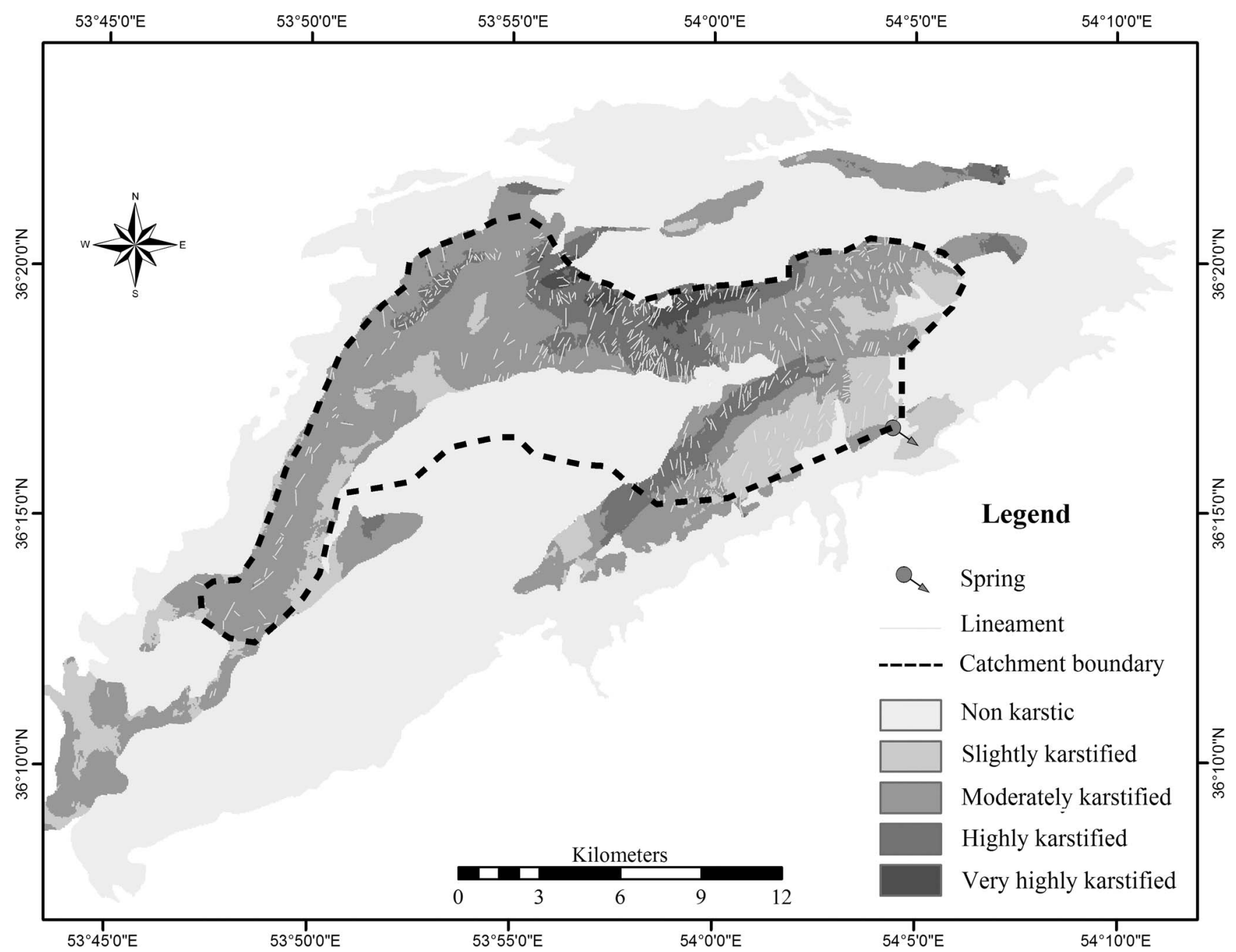

Figure 3. The relative surface karstification in the study area determined by weighting the data in the layers of Figure 2 according to the percentages in Table 1. 
Table 2. Determination of the average surface karstification $(\%)$ in the Cheshme-Ali basin based on area and karstification coefficient at each level of karstification intensity.

\begin{tabular}{lcc}
\hline $\begin{array}{l}\text { Karst Development } \\
\text { Classification }\end{array}$ & $\begin{array}{c}\text { Area, } \\
\mathrm{km}^{2}\end{array}$ & $\begin{array}{c}\text { Karstification } \\
\text { Coefficient, \% }\end{array}$ \\
\hline Slightly karstified & 24.3 & 25 \\
Moderately karstified & 81.0 & 50 \\
Highly karstified & 25.1 & 75 \\
Very highly karstified & 3.58 & 100 \\
Surface Karstification $=51.47 \%$ & \\
\hline
\end{tabular}

krastification according to actual surficial elements should be taken into account when estimating karstification coefficient. In fact, the coefficients represent relative potential of the surface of terrains regarding their potential of permeability and dissolution. If a class has a general low potential of karstification, it gets a low weight and vice versa. Although the proposed indices are based on logical numerical values, they are inherently qualitative criteria. The mean surface karstification of the Cheshme-Ali catchment is $51.47 \%$, which suggests a moderate karstification rate.

\section{Structural Analysis}

Cheshme-Ali aquifer is recharged only by direct precipitation over bare limestones, through joints, fractures and discontinuous elements. Aloui and Chaabani (2006) presented a statistical method for evaluation of karstification in fractures at Jebel Feriana in Tunisia that is used here as well. Based on this method, karstification of bedrock $I_{k}$ is proportional to openness and fracture intensity and can be estimated $I_{k}=O \times I_{f}$, where $O$ represents the average openness and $I_{f}$ describes the characteristic fracturing of the site (Aloui and Chaabani, 2006).
The fracture characteristic of a site is defined by $I_{f}=\left(n \times n_{c}\right) /(s \times e)$, where $s$ represents surface, $n$ is the number of fractures, $n_{c}$ is the number of beds crossed by fractures (i.e., fracture depths) and $e$ is the mean fracture spacing (Aloui and Chaabani, 2006). In this study, fracture characteristics have been measured at different stations for evaluating the surface karst development (Fig. 4). The limestone layer is very thick in the study area; therefore, the number of beds $n_{c}$ has been considered as single unit. The numerical result of karstification in fractures at several stations of the Cheshme-Ali Basin is shown in Table 3. The mean openness of fractures in the Cretaceous and Lar Formations is higher than the Dalichai Formation. Therefore, the karstification index $I_{k}$ is expected to have higher values in Lar and Cretaceous Formations.

\section{Hydrograph and Chemograph Analysis}

Response of an aquifer to external precipitation pulses can be reflected in springs' hydrographs and chemographs, which are mainly controlled by internal flow paths and karstification of the aquifer. The Cheshme-Ali Spring is the only resurgence of the studied aquifer. The discharge rates and the main physicochemical parameters of the spring were measured monthly for two periods during 2003-2004 (first year) and 2010-2011 (second year) by Karami (2004) and Shokri (2012), respectively. The only input to the aquifer is the direct diffuse recharge of precipitation over anticlines.

The maximum (minimum) measured discharge rates are 435 (391) and 755 (425) $\mathrm{L} \mathrm{s}^{-1}$ in the first and second year, respectively. Although the ratio of maximum to minimum discharge is relatively low in both measured periods, the flow rate differences are notably high between the two periods. Daily rainfall data were plotted to compare spring discharge fluctuation (Fig. 5). The total annual rainfall, according to the Astane station, was 99 and $114 \mathrm{~mm}$ in the first and second years, respectively. Such a small difference
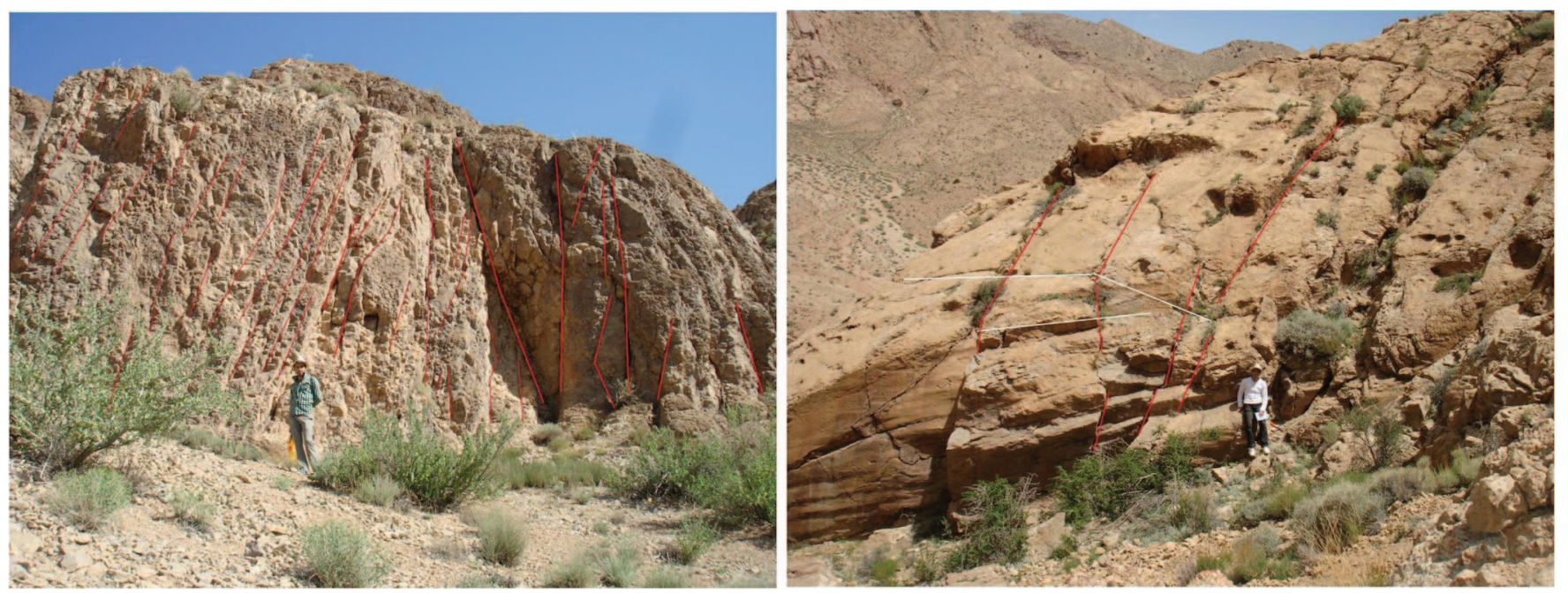

Figure 4. Examples of fractures in different stations of the Cheshme-Ali basin. 
Table 3. Fracture characteristics in several stations of the three karst formations of the Cheshme-Ali basin. The components of the table are described in the text.

\begin{tabular}{|c|c|c|c|c|c|c|c|c|c|}
\hline \multirow[b]{2}{*}{ No } & \multirow[b]{2}{*}{ Formation } & \multicolumn{2}{|c|}{ Location } & \multirow[b]{2}{*}{$n$} & \multirow[b]{2}{*}{$e, \mathrm{~cm}$} & \multirow[b]{2}{*}{$S, \mathrm{~m}^{2}$} & \multirow[b]{2}{*}{$O, \mathrm{~cm}$} & \multirow[b]{2}{*}{$I_{f}$} & \multirow[b]{2}{*}{$I_{k}$} \\
\hline & & Latitude, ${ }^{\circ} \mathrm{N}$ & Longitude, ${ }^{\circ} \mathrm{E}$ & & & & & & \\
\hline 1 & Dalichai & $36^{\circ} 17^{\prime} 03^{\prime \prime}$ & $54^{\circ} 03^{\prime} 13^{\prime \prime}$ & 6 & 64 & 23 & 1.2 & $4.1 \times 10^{5}$ & 4920 \\
\hline 2 & Dalichai & $36^{\circ} 17^{\prime} 12^{\prime \prime}$ & $54^{\circ} 03^{\prime} 35^{\prime \prime}$ & 10 & 30.5 & 28 & 0.8 & $1.2 \times 10^{6}$ & 9600 \\
\hline 3 & Dalichai & $36^{\circ} 15^{\prime} 28^{\prime \prime}$ & $54^{\circ} 00^{\prime} 51^{\prime \prime}$ & 14 & 82.3 & 33 & 1.63 & $5.2 \times 10^{5}$ & 8476 \\
\hline 4 & Dalichai & $36^{\circ} 14^{\prime} 21^{\prime \prime}$ & $53^{\circ} 58^{\prime} 48^{\prime \prime}$ & 8 & 52 & 25 & 1.35 & $6.1 \times 10^{5}$ & 8235 \\
\hline 5 & Dalichai & $36^{\circ} 17^{\prime} 50^{\prime \prime}$ & $54^{\circ} 03^{\prime} 03^{\prime \prime}$ & 8 & 115 & 35 & 1.1 & $2.0 \times 10^{5}$ & 2200 \\
\hline 6 & Cretaceous & $36^{\circ} 18^{\prime} 10^{\prime \prime}$ & $54^{\circ} 02^{\prime} 14^{\prime \prime}$ & 6 & 90 & 15 & 1.4 & $4.4 \times 10^{5}$ & 6160 \\
\hline 7 & Cretaceous & $36^{\circ} 17^{\prime} 57^{\prime \prime}$ & $54^{\circ} 01^{\prime} 44^{\prime \prime}$ & 5 & 130 & 41 & 2.6 & $9.4 \times 10^{4}$ & 2444 \\
\hline 8 & Cretaceous & $36^{\circ} 17^{\prime} 35^{\prime \prime}$ & $54^{\circ} 01^{\prime} 19^{\prime \prime}$ & 7 & 70 & 26 & 3.5 & $4.0 \times 10^{5}$ & 14000 \\
\hline 9 & Lar & $36^{\circ} 17^{\prime} 47^{\prime \prime}$ & $53^{\circ} 51^{\prime} 10^{\prime \prime}$ & 6 & 37 & 13 & 1.6 & $1.2 \times 10^{6}$ & 19200 \\
\hline 10 & Lar & $36^{\circ} 17^{\prime} 47^{\prime \prime}$ & $53^{\circ} 51^{\prime} 31^{\prime \prime}$ & 11 & 115 & 20 & 2.95 & $4.7 \times 10^{5}$ & 14108 \\
\hline 11 & Lar & $36^{\circ} 17^{\prime} 34^{\prime \prime}$ & $53^{\circ} 51^{\prime} 57^{\prime \prime}$ & 18 & 55 & 30 & 4.2 & $1.1 \times 10^{6}$ & 46200 \\
\hline 12 & Lar & $36^{\circ} 17^{\prime} 47^{\prime \prime}$ & $53^{\circ} 52^{\prime} 10^{\prime \prime}$ & 14 & 120 & 38 & 3.6 & $3.1 \times 10^{5}$ & 11160 \\
\hline
\end{tabular}

in annual rainfall cannot be the cause of the large discharge difference in the spring. The time distributions of rainfalls were compared to the discharge curve of the spring in both periods. In the rainy season, the rainfall distribution was more uniform over time in the first period relative to the second period. The most important rainfall event was an intense precipitation of $53 \mathrm{~mm}$ during three consecutive days, March 11-14, 2011, which is equal to about half of the annual rainfall in the second year. The peak discharge was detected after two months lag time, whereas it was estimated to be five months in the earlier year (Fig. 5).

A recession curve is the portion of the hydrograph that extends from a discharge peak to the base of the next rise. To determine flow regime of the spring, Mangin's approach (1975) was used. The exponential coefficients $\alpha$ represent inherent aquifer characteristics such as material porosity and internal karstification (Amit et al., 2002;
Kovács et al., 2005; Fiorillo, 2011). The results of analysis are presented in Table 4. Only one recession coefficient, $\alpha$, which is a rare situation in practice, was obtained in the two periods of measurements. The recession coefficient of the spring in the second period is seven times that of the first period. There is no quick flow in the first year, but a small amount of water $(0.3 \%)$ emerges as a quick-flow component in the second period. Thus, the aquifer flow is diffuse. Also, the presence of well-interconnected karst fissures, along with the absence of large caves in the phreatic zone, can regulate water discharge and smooth variation in a hydrograph. According to Malik (2007), the inner karstification of the spring's catchment area is categorized as low degree.

Geological investigation demonstrated that the Lar Formation has more potential for karstification than the Dalichai Formation due to its high purity. The Lar and
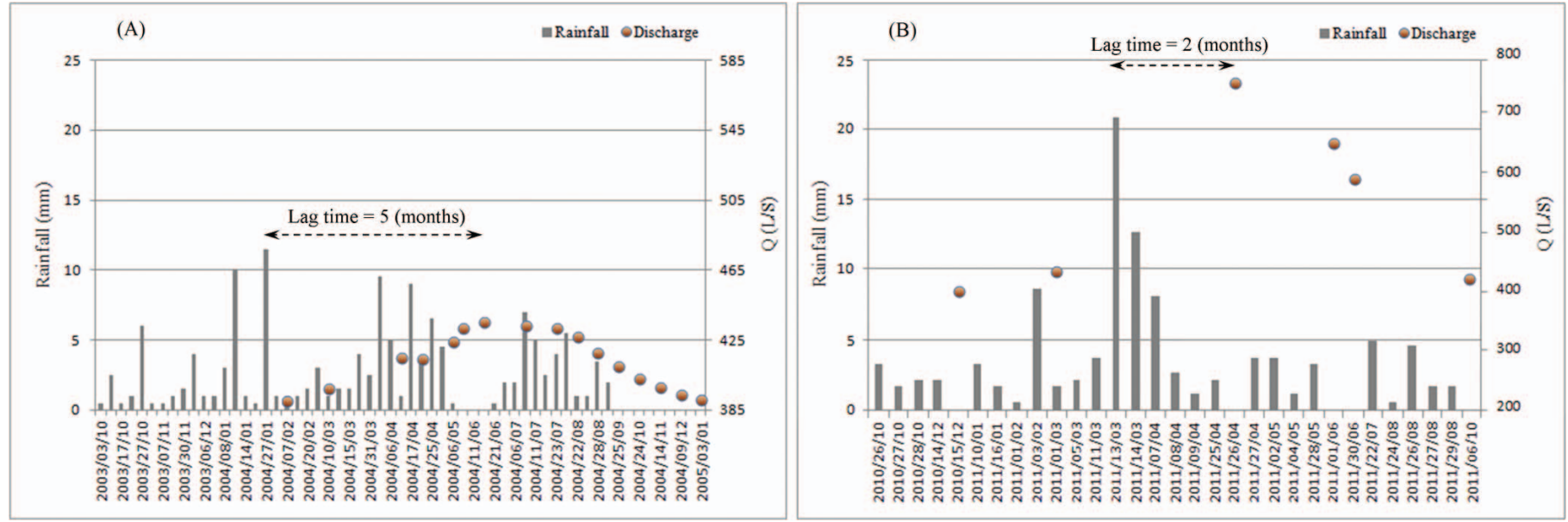

Figure 5. The records of daily rainfall and discharge of the Cheshme-Ali Spring during the 2003-2004 study year (A) and the 2010-2011 study year (B). Note that while the rainfall scales are the same in the two parts, the discharge scales are not. 
Table 4. Summary of the main characteristics of the recession curve analysis of the Cheshme-Ali Spring in different hydrological years. Sufficient details regarding the components of the table are presented below.

\begin{tabular}{lcccccccccc}
\hline Year & $\begin{array}{c}Q_{\text {max }}, \\
\mathrm{m}^{3} \mathrm{~s}^{-1}\end{array}$ & $\begin{array}{c}Q_{\text {min }}, \\
\mathrm{m}^{3} \mathrm{~s}^{-1}\end{array}$ & $\begin{array}{c}q_{0}{ }^{b}, \\
\mathrm{~m}^{3} \mathrm{~s}^{-1}\end{array}$ & $\alpha, \mathrm{d}^{-1}$ & $\begin{array}{c}q_{0}{ }^{*}, \\
\mathrm{~m}^{3} \mathrm{~s}^{-1}\end{array}$ & $t_{i}, \mathrm{~d}$ & $\mu, \mathrm{d}^{-1}$ & $\varepsilon, \mathrm{d}^{-1}$ & $\left(V_{0}^{b} / V_{0}\right), \%$ & $\left(V_{0}^{*} / V_{0}\right), \%$ \\
\hline $2003-2004$ & 0.435 & 0.391 & 0.435 & $5.20 \times 10^{-4}$ & $\ldots$ & $\ldots$ & $\ldots$ & $\ldots$ & 100 & $\ldots$ \\
$2010-2011$ & 0.755 & 0.425 & 0.720 & $3.53 \times 10^{-3}$ & 0.035 & 36 & 0.027 & 0.0335 & 99.7 & 0.3 \\
\hline
\end{tabular}

Notes: $Q_{\max }$ and $Q_{\min }$ are, respectively, maximum and minimum discharge of the spring; $q_{0}^{b}$, discharge at the beginning of the recession for the base flow; $\alpha$, baseflow coefficient; $q_{0}{ }^{*}$, discharge at the beginning of recession for the quickflow, $t_{i}$, duration of quickflow; $\mu$ and $\varepsilon$, parameters adapted for the curves of the quickflow; $V_{0}$, total dynamic aquifer volume; $V_{0}^{b}$ and $V_{0}^{*}$ are initial volumes that will be drained during baseflow and quickflow.

Cretaceous Formations are exposed in more than $90 \%$ of the spring's catchment area, while the Dalichai Formation crops out in about $10 \%$ of the catchment, near the spring. The aquifer must collect groundwater from the Lar and Cretaceous Formations and deliver it to the Dalichai Formation. Since Dalichai is not a heavily karsted water-bearing layer, it acts as regulator of the groundwater flow. Although the majority of the groundwater discharging at the spring originates from the Lar and Cretaceous Formations, hydraulic responses to external pulses are controlled by the Dalichai Formation.

The water table fluctuates up and down as a result of seasonal and annual change in precipitation and drought and wet conditions that create pathways near the water table and provide a very fast way to transport water in an aquifer. During high recharge or wet cycles, the water table, especially proximal to a spring, may be higher than the typical elevation of the water table. This hypothesis can explain the short lag time during the second year, 20102011 , as due to the high rate of precipitation in those three days and the consequent recharge to the aquifer.

Grasso et al. (2003) stated that the concentration of dissolved materials in a spring is a function of discharge rate. This relationship allows for the prediction of aquifer

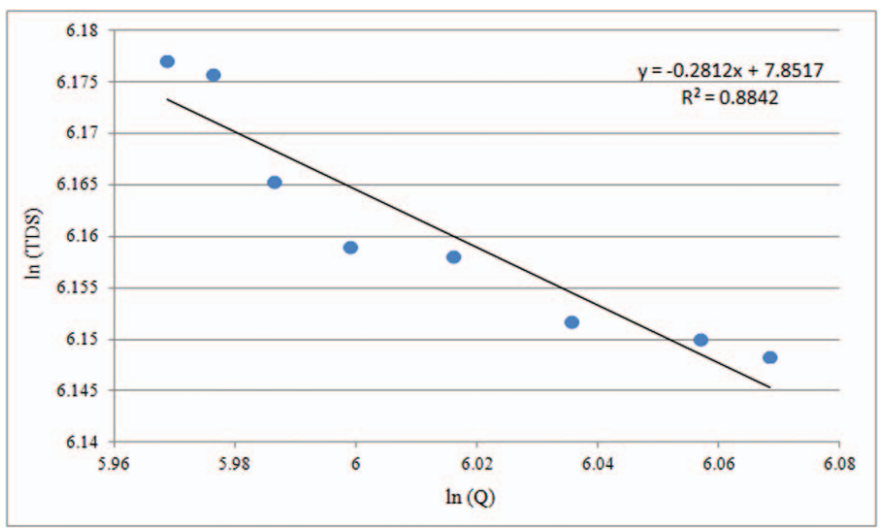

Figure 6. The relationship between discharge of the Cheshme-Ali Spring and its total dissolved solids concentration in a log-log plot. The parameters of the line are used to estimate the index of subsurface karstification of the aquifer. geometry (volume/surface ratio and mean flow-path length). The relationship of concentration and discharge allows us to estimate two parameters, $\alpha$ and $A$, where $A$ is a function of calcite saturation and $\alpha$ depends on the spatial dimension of the karstic network based on $\ln \left(C_{t}\right)=\ln (A)-\alpha \ln \left(Q_{t}\right)$. By depicting $\ln (C)$ versus $\ln (Q)$ on a graph, the $\alpha$ and $A$ parameters can be determined. Graphically, $\alpha$ is equal to the slope of the line and $A$ will be recognized by extrapolating the line to the vertical axis. Concentration is, however, dependent on two geometric parameters of conduit networks, the area-to-volume ratio $(A V R)$ and the average flow path $(A F P)$. The $A V R$ is dependent on the average void aperture of the submerged karstic networks which can be considered as a karstification index and used for comparison of different karst systems (Grasso et al., 2003). The $\alpha$ parameter shows an intrinsic characteristic of each karstic system that varies directly with the conduit networks $A V R$ s and inversely with their $A F P$ s according to $\alpha=1900 A V R / A F P$ (Grasso et al., 2003).

The AFP depends on the hydrogeological catchment area of the spring and is estimated from the square root of its area. The result of plotting $\ln \left(C_{t}\right)$ versus $\ln \left(Q_{t}\right)$, where $C_{t}$ is total dissolved solids, for Cheshme-Ali Spring is shown in Figure 6. $\alpha$ is equal to 0.2812 , and $A$ is equal to 2565 $(\ln (A)$ is 7.85$)$. The average flow path $A F P$, which has been estimated as the square root of the catchment area, is 11.48 $\mathrm{km}$. From these calculations, the area-to-volume ratio $A V R$, which is also referred to as the karstification index, is estimated to be $1.7 \mathrm{~m}$ based on the calculation of $\alpha$. The estimated value shows a low to average extent of karstification.

\section{Conclusions}

The surface and subsurface indexes are signatures of karst development that can reflect hydraulic characteristics and the physicochemical response of karst aquifers. GIS and remote-sensing studies revealed that the karstification rate is moderate in the catchment area of Cheshme-Ali Spring. It is also possible to determine spatial zonation of karstification at the regional scale. The physicochemical characteristics of Cheshme-Ali Spring indicated that the 
subsurface karstification is moderate, and it is unlikely to determine its variation in the aquifer by the spring hydrochemical analysis.

Lithologically, the spring catchment area consists of distal limestone and proximal marly limestone relative to the spring's location. The latter is less karstified than the limestone portion and provides a groundwater flow regulator, limiting the discharge of the spring. The presence of this heterogeneity and the elongated shape of the aquifer cause the aquifer to store water for long periods and discharge water continuously and smoothly during the arid season. Consequently, in spite of a clear definition of karstification degree, we need to explore a comprehensive quantitive method to evaluate the karstification degree in geomorphologic, hydraulic, and engineering aspects. The main limit of this work has been the absence of a long period of discharge and physicochemical records of the spring with high temporal resolution. Ideally, these data would be available at least at a weekly interval for a minimum of two years. These data could provide a link between precipitation variability and fluctuations, as well as flow paths and spring response to external pulses.

\section{ACKNOWLEDGEMENTS}

This research was supported financially by Shahrood University of Technology. The authors would like to thank Dr. Peter Malik for his valuable points as well as anonymous reviewers for their insightful reviews and comments. We are also grateful to Amanda Laskoskie for her careful and detailed review, which helped to improve the final manuscript.

\section{REFERENCES}

Aghanabati, A., 2006, Geology of Iran: Tehran, Ministry of Industry and Mines, Geological Survey of Iran, (in Persian) $587 \mathrm{p}$.

Aloui, T., and Chaabani, F., 2006, Influence of fractures and karstification on development of a quarry at Jebel Feriana, Tunisia: Bulletin of Engineering Geology and the Environment, v. 66, p. 345-351. doi:10.1007/s10064-006-0073-y.

Amit, H., Lyakhovsky, V., Katz, A., Starinsky, A., and Burg, A., 2002, Interpretation of spring recession curves: Groundwater, v. 40, p. 543-551. doi:10.1111/j.1745-6584.2002.tb02539.x.

Ashjari, J., and Raeisi, E., 2006, Influence of anticlinal structure on regional flow, Zagros, Iran: Journal of Cave and Karst Studies, v. 68, no. 3, p. $118-129$.

Daman Afshar, H., and Majlesi, M., 2013, GIS and the Analytic Hierarchy Process method for site selection of waste landfills: A case study in Iran: International Journal of Geology, Earth \& Environmental Sciences, v. 3, no. 3, p. 96-104.

De Waele, J., Plan, L., and Audra, P., 2009, Recent developments in surface and subsurface karst geomorphology: An introduction: Geomorphology, v. 106, p. 1-8. doi:10.1016/j.geomorph.2008.09.023.

De Waele, J., Gutiérrez, F., Parise, M., and Plan, L., 2011, Geomorphology and natural hazards in karst areas: a review. Geomorphology, v. 134, p. 1-8. doi:10.1016/j.geomorph.2011.08.001.

Dewandel, B., Lachassagne, P., Bakalowicz, M., Weng, P., and Al-Malki, A., 2003, Evaluation of aquifer thickness by analyzing recession hydrographs. Application to the Oman ophiolite hard-rock aquifer:
Journal of Hydrology, v. 274, p. 248-269. doi:10.1016/S00221694(02)00418-3.

Drake, J.J., and Harmon, R.S., 1973, Hydrochemical environments of carbonate terrains: Water Resources Research, v. 9, no. 4, p. 949-957. doi:10.1029/WR009i004p00949.

Fiorillo, F., 2011, Tank-reservoir drainage as a simulation of the recession limb of karst spring hydrographs: Hydrogeology Journal, v. 19, p. 1009-1019. doi:10.1007/s10040-011-0737-y.

Ford, D., and Williams, P., 2007, Karst Hydrogeology and Geomorphology, Chichester, England, John Wiley \& Sons Ltd, 562 p.

Goldscheider, N., Drew, D. eds. 2007, Methods in Karst Hydrogeology, London, Taylor and Francis, International Contributions to Hydrogeology 26, $264 \mathrm{p}$.

Grasso, D.A., Jeannin, P.-Y., and Zwahlen, F., 2003, A deterministic approach to the coupled analysis of karst springs' hydrographs and chemographs: Journal of Hydrology, v. 271, p. 65-76. doi:10.1016/ S0022-1694(02)00321-9.

Gutiérrez, F., Parise, M., De Waele, J., and Jourde, H., 2014, A review on natural and human-induced geohazards and impacts in karst: EarthScience Reviews, v. 138, p. 61-88, doi:10.1016/j.earscirev.2014.08.002.

Ho, W., 2008, Integrated analytic hierarchy process and its application - a literature review: European Journal of Operational Research, v. 186, p. 211-228. doi:10.1016/j.ejor.2007.01.004.

Jafarbeyglou, M., Moghimi, E., and Safari, F., 2012, Evaluating morphotectonic karst sinks in Parav-Bistoun mass using DEM: Geography and Environmental Planning Journal, v. 22, no. 4, p. 1-4.

Jameson, R.A., 2006, Identification and analysis of early flow paths in branchwork caves in West Virginia, USA, in Harmon, R.S., and Wicks, C.M., eds., Perspectives on Karst Geomorphology, Hydrology, and Geochemistry:Geological Society of America Special Papers, v. 404, p. 23-30. doi:10.1130/2006.2404(03).

Jeannin, P.Y., and Sauter, M., 1998, Analysis of karst hydrodynamic behavior using global approach: A review. Bulletin d'Hydrogéologie, no. 16 , p. $31-48$.

Karami, G.H., 2004, Hydrogeological and hydrochemical assessment of the Damghan's Cheshme-Ali Spring: Final report of research proposal, code 2107, Shahrood, Shahrood University of Technology, $57 \mathrm{p}$.

Kiraly, L., 2003, Karstification and groundwater flow: Speleogenesis and Evolution of Karst Aquifers, v. 1, n. 3. 26 p.

Kovács, A., Perrochet, P., Király, L., and Jeannin, P.-Y., 2005, A quantitative method for the characterisation of karst aquifers based on spring hydrograph analysis: Journal of Hydrology, v. 303, p. 152-164. doi:10.1016/j.jhydrol.2004.08.023.

Malik, P., 2007, Assessment of regional karstification degree and groundwater sensitivity to pollution using hydrograph analysis in the Velka Fatra Mountains, Slovakia: Environmental Geology, v. 51, p. 707-711. doi:10.1007/s00254-006-0384-0.

Mangin, A., 1975, Contribution à l'étudehydrodynamique des aquifèreskarstiques, [Ph.D. Dissertation]: Dijon, Univ. de Dijon, 124 p.

Melelli, L., Gregori, L., and Mancinelli, L., 2012, The use of remote sensed data and GIS to produce a digital geomorphological map of a test area in central Italy, in Chemin, Y., ed., Remote Sensing of Planet Earth: InTech open access book, http://www.intechopen.com/ books/remote-sensing-of-planet-earth/the-use-remote-sensed-dataand-gis-to produce-a-digital-geomorphological-map-of-a-test-area-incentr,[accessed July 2, 2013]. doi:10.5772/34564.

Mondal, S., and Maiti, R., 2013, Integration the Analytical Hierarchy Process (AHP) and the frequency ration (FR) model in landslide susceptibility mapping of Shiv-khola watershed, Darjeeling Himalays: International Journal of Disaster Risk Science, v. 4, no. 4, p. 200-212. doi:10.1007/s13753-013-0021-y.

Panagopoulos, G., and Lambrakis, N., 2006, The contribution of time series analysis to the study of the hydrodynamic characteristics of karst systems: Application on two typical karst aquifers of Greece (Trifilia, Almyros Crete): Journal of hydrology, v. 329, p. 368-376. doi:10.1016/j.jhydrol.2006.02.023.

Parise, M., 2008, Rock failures in karst, in Chen, Zuyu, Zhang, Jian-Min,, Li, Zhong-Kui, Wu, Fa-Quan, and Ho, Ken, eds., Landslides and Engineered Slopes. From the Past to the Future. Proc. 10th International Symposium on Landslides, Xi'an (China), June 30-July 4, 2008: CRC Press, vol. 1, 275-280.

Parise, M., Closson, D., Gutiérrez, F., and Stevanović, Z., 2015, Anticipating and managing engineering problems in the complex 
karst environment: Environmental Earth Sciences, published online June 2015. doi:10.1007/s12665-015-4647-5.

Pepe, M., and Parise, M., 2014, Structural control on development of karst landscape in the Salento Peninsula (Apulia, SE Italy): Acta Carsologica, v. 43, no. 1, p. 101-114. doi:10.3986/ac.v43i1.643.

Sauter, M., 1992, Quantification and Forecasting of Regional Groundwater Flow and Transport in a Karst Aquifer (Gallusquelle, Malm, SW Germany): Tübinger Geowissenschaftliche Arbeiten, C13, 150 p.

Šebela, S., Gosar, A., Košt'ák, B., and Stemberk, J., 2005, Active tectonic structures in the W part of Slovenia-Setting of micro-deformation monitoring net: Acta Geodynamicaet Geomaterialia, v. 2, no. 1, p. 45-57.

Shokri, M., 2012, Assessment of Karst development in Damghan's Cheshme-Ali basin by compiling hydrogeological studies, GIS and RS, [M.S. Thesis]: Shahrood, Shahrood University of Technology, (in Persian) $165 \mathrm{p}$

Shokri, M., Ashjari, J., and Karami, G.H., 2011, Influence of tectonic and stratigraphy on groundwater flow direction in Damghan's Cheshme-
Ali basin, in Proceedings, $15^{\text {th }}$ Symposium of the Geological Society of Iran: Tehran, Tarbiat Moalem University, (in Persian) 526 p.

Sinha, R., Bapalu, G.V., Singh, L.K., and Rath, B., 2008, Flood risk analysis in the Kosi river basin, north Bihar using multi-parametric approach of Analytical Hierarchy Process (AHP): Journal of the Indian Society of Remote Sensing, v. 36, no. 4, p. 335-349. doi:10.1007/s12524-008-0034-y.

Stöcklin, J., and Setudehnia, A., 1971, Stratigraphic Lexicon of Iran, Part 1: Central, North, and East Iran: Geological Survey of Iran Report no. $18,376 \mathrm{p}$.

White, W.B., 1988, Geomorphology and Hydrology of Karst Terrains, Oxford, Oxford University Press, $464 \mathrm{p}$.

White, W.B., 2002, Karst hydrology: Recent development and open questions: Engineering Geology, v. 65, p. 85-105. doi:10.1016/S00137952(01)00116-8

Wulff, H.E., 1968, The qanats of Iran: Scientific American, v. 218, no. 4, p. $94-105$. 